\title{
PERANAN NAKHODA DALAM MEMOTIVASI SEMANGAT KERJA KRU DI ATAS KAPAL KN. BIMA SAKTI
}

\author{
Firdaus Sitepu
}

Dosen PIP Semarang

\begin{abstract}
The role of the skipper to give motivation to the crew work is urgently needed to provide impetus in implementing the tasks and jobs on the boat and avoid delay and buildup. The method used in this research is descriptive qualitative. Data were obtained using the technique of direct interviews and a questionnaire that is provided to the crew. And to receive data from the literature related to the title of this research. The conclusion of this study is the motivation of the crew on board was influenced by encouragement from the skipper. And the result is positive. The crew's performance is getting better and this is expected to be mainted.
\end{abstract}

\section{Keywords : motivation, crew, KN. Bima Sakti}

\begin{abstract}
ABSTRAK
Peranan Nakhoda untuk memberikan motivasi kerja kepada anak buah kapal sangat dibutuhkan untuk memberikan dorongan dalam melaksanakan tugas dan pekerjaan di atas kapal dan tidak terjadi penundaan dan penumpukan. Metode yang digunakan dalam penelitian ini adalah deskriptif kualitatif. Populasi dalam penelitian ini adalah semua kru yang bekerja di atas kapal KN. BIMA SAKTI. Data yang diperoleh menggunakan teknik wawancara langsung dan dengan kusioner yang di berikan kepada kru. Serta mendapat dalam penelitian ini adalah motivasi kerja kru di atas kapal dipengaruhi oleh dorongan dari Nakhoda. Dan hasilnya posiitif. Kinerja kru semakin membaik dan diharapkan ini dapat dipertahankan.
\end{abstract}

Kata kunci : motivasi, kru, KN. Bima Sakti

\section{PENDAHULUAN}

Indonesia merupakan negara maritim yang terdiri dari pulau-pulau yang dipisahkan oleh lautan. Untuk memudahkan berbagai macam aktifitas di atas laut diperlukan sebuah alat trasportasi. Kapal laut merupakan sarana transportasi yang penting dalam aktifitas hubungan antara masyarakat dari pulau satu dengan pulau lainnya. Pemimpin di atas kapal adalah Nakhoda. Nakhoda mempunyai wewenang dan tanggung jawab penuh atas terlaksananya pelayaran yang baik berkaitan dengan keselamatan kapal, muatan, penumpang, keselamatan kru kapalnya serta memotivasi awak kapal agar selalu memperhatikan dan mematuhi ketentuan sistem manajemen keselamatan.

Motivasi kerja merupakan salah satu faktor yang dapat meningkatan kinerja kru. Baik buruknya kinerja kru ditentukan oleh motivasi. Kru agar mau bekerja pada umumnya harus mempunyai motivasi. Motivasi berarti suatu kondisi yang mendorong atau menjadi penyebab seorang melakukan suatu perbuatan atau kegiatan, yang berlangsung secara sadar (Nawawi, 2000 : 87). Menurut Steer (2001), faktor yang mempengaruhi kinerja 
Firdaus Sitepu

adalah motivasi kerja, selanjutnya menjelaskan bahwa motivasi mempunyai kekuatan kecenderungan seseorang atau individu untuk melibatkan diri dalam kegiatan yang mengarah kepada sasaran dalam pekerjaan sebagai kepuasaan, tetapi lebih lanjut merupakan perasaan senang atau rela bekerja untuk mencapai tujuan pekerjaan, sehingga pekerjaan bias selesai tepat waktu.

Dalam Undang-Undang N0. 21 Tahun 1992 tentang pelayaran mendefinisikan "Pemimpin kapal itu adalah salah seorang dari awak kapal yang menjadi pimpinan umum di atas kapal untuk jenis dan ukuran tetentu serta mempunyai wewenang dan tanggung jawab tertentu, berbeda yang dimiliki Nakhoda".

"Nakhoda kapal adalah salah seorang dari awak kapal yang menjadi pimpinan umum di atas kapal dan mempunyai wewenang dan tanggung jawab tertentu sesuai dengan peraturan dan perundang-undangan yang berlaku."

"Awak kapal adalah orang yang bekerja atau dipekerjakan di atas kapal oleh pemilik atau operator kapal untuk melakukan tugas di atas kapal sesuai dengan jabatannya yang tercantum dalam buku sijil."

Sebagai makhluk sosial manusia membutuhkan bantuan orang lain. Manusia akan selalu berusaha untuk memenuhi kebutuhannya dan memerlukan motivasi atau dorongan dari orang lain untuk mencapai apa yang menjadi tujuan hidupnya.

Pimpinan organisasi atau perusahaan merupakan orang yang bekerja dengan bantuan dari para bawahannya, yaitu karyawan. Oleh karena itu, sudah menjadi kewajiban dari seorang pimpinan untuk mengusahakan agar para karyawan berprestasi. Kemampuan bawahan untuk dapat berprestasi disebabkan dengan adanya dorongan atau motivasi.
Pemberian motivasi dengan tepat akan dapat menimbulkan semangat, gairah dan keikhlasan kerja dalam diri seseorang. Meningkatnya kegairahan dan kemauan untuk bekerja dengan sukarela tersebut akan menghasilkan pekerjaan yang lebih baik, sehingga akan meningkatkan produktivitas kerja. Sedangkan seseorang yang mempunyai motivasi kerja rendah, mereka akan bekerja seenaknya dan tidak berusaha untuk mendapatkan hasil yang maksimal.

Motivasi kerja dapat memberi energi yang menggerakkan segala potensi yang ada, menciptakan keinginan yang tinggi dan luhur serta meningkatkan kegairahan dan kebersamaan.

Dari pengertian motivasi kerja di atas, mendorong beberapa ahli untuk ikut berpendapat mengenai motivasi kerja meliputi:

1. Menurut Pandji Anoraga Motivasi kerja adalah kemauan kerja karyawan yang timbulnya karena adanya dorongan dari dalam pribadi karyawan yang bersangkutan sebagai hasil integrasi keseluruhan daripada kebutuhan pribadi, pengaruh lingkungan fisik dan pengaruh lingkungan sosial dimana kekuatannya tergantung daripada proses pengintegrasian tersebut.

2. Ernest J. McCormick Motivasi kerja adalah kondisi yang berpengaruh membangkitkan, mengarahkan dan memelihara perilaku yang berhubungan dengan lingkungan kerja.

3. Berelson dan Steiner dalam Siswanto Sastrohadiwiryo, motivasi kerja adalah Keadaan kejiwaan dan sikap mental manusia yang memberikan energi, mendorong kegiatan atau menggerakkan dan mengarah atau menyalurkan perilaku ke arah mencapai kebutuhan yang memberi kepuasan atau mengurangi ketidakseimbangan. 
Dari pendapat-pendapat di atas dapat disimpulkan bahwa motivasi kerja adalah sesuatu yang mendorong seseorang, baik berasal dari dalam maupun dari luar diri seseorang, sehingga seseorang tersebut akan memiliki semangat, keinginan dan kemauan yang tinggi untuk melaksanakan aktivitas kerja.

Begitu pula di atas kapal pada kenyataannya masih banyak pekerjaan yang tidak selesai sesuai dengan jadwal yang telah ditentukan, hal ini disebabkan karena kurangnya semangat kerja kru di atas kapal.

Salah seorang pelaut mengemukakan pengalamannya pada saat kapal sandar di pelabuhan dalam Tanjung Mas terjadi perkelahian antara kru kapal yang berawal dari adu mulut, hal ini disebabkan karena salah seorang kru berhenti bekerja sebelum waktu yang telah ditetapkan di atas kapal sedangkan target pekerjaan yang ingin diselesaikan saat itu masih banyak yang belum selesai sehingga bosun marah dan menegur kru tersebut karena kru tersebut mersa tersinggung perkelahian tersebut tidak dapat dihindari, dengan kejadian ini membuat kurangnya hubungan yang harmonis antara kru kapal. Hal ini terjadi karena kurangnya perhatian dari perwira kapal khususnya Nakhoda, kurangnya perhatian Nakhoda membuat kru kurang termotivasi dalam bekerja sehingga banyak kru yang bermalas-malasan dalam bekerja yang mengakibatkan banyak pekerjaan yang tidak selesai sesuai dengan target yang telah ditentukan.

Rendahnya motivasi kerja yang dimiliki oleh awak kapal karena kejenuhan yang dialami karena masa kontrak kerja yang sudah lewat, juga kurangnya komunikasi antara Nakhoda dan crew. Permasalahan ini perlu segera diatasi, sehingga kinerja awak kapal dapat meningkat lagi sehingga pengoperasian kapal dapat berjalan lancar seperti yang diharapkan.

Sesuai hal tersebut di atas, maka peneliti terdorong untuk melakukan penelitian dengan judul "Peranan Nakhoda Dalam Memotivasi Semangat Kerja Kru Di Atas Kapal KN. Bima Sakti”.

Berdasarkan latar belakang di atas, maka rumusan masalah dalam penelitian ini adalah bagaimana hubungan peranan nakhoda terhadap peningkatan motivasi kerja kru di atas kapal ?

Tujuan penelitian ini adalah untuk mengetahui peranan Nakhoda dalam memotivasi semangat kerja kru di atas kapal.

a. Untuk mengidentifikasi masalah mengapa kinerja $\mathrm{ABK}$ menurun di atas kapal.

b. Untuk mengetahui penyebab dalam masalah peran dan tanggung jawab Nakhoda dalam meningkatkan kinerja ABK di atas kapal sehingga pengoperasian kapal dapat berjalan dengan baik.

c. Untuk mencari upaya meningkatkan kinerja ABK dalam mengoperasikan kapal.

\section{METODE PENELITIAN}

\section{A. Populasi dan Sempel}

Populasi dalam penelitian ini adalah semua kru yang bekerja di atas kapal. Adapun sampel kru dalam penelitian ini adalah kru kapal KN. Bimasakti

\section{B. Teknik Pengumpulan Data}

Dalam pengumpulan data mengenai variabel yang akan diteliti, peneliti menggunakan teknik :

1. Kuesioner (angket) pilihan ganda yang akan disebarkan kepada responden. Kuesioner ini digunakan untuk mengukur variabel motivasi dari nakhoda kepada kru di atas kapal.

2. Wawancara, tanya jawab yang dilakukan dengan responden untuk memperoleh informasi tentang kejadian-kejadian di atas kapal selama mereka sandar atau berlayar 
Firdaus Sitepu

dan informasi guna melengkapi data yang belum terjadi melalui kuesioner.

\section{Teknik Analisis Data}

Dari data penelitian yang terkumpul, selanjutnya dianalisis dengan menggunakan teknik analisis deskriptif kualitatif. Teknik ini dimaksudkan untuk menggambarkan peranan Nakhoda dalam memotivasi semangat kerja para kru di atas kapal.

\section{HASIL PENELITIAN DAN PEMBAHASAN}

Analisis diskriptif yaitu analisis yang digunakan untuk menggambarkan data yang diperoleh dari responden. Dalam hal ini persepsi responden terhadap pengaruh Nakhoda dalam memotivasi semangat kerja kru di atas kapal.

Kehidupan di atas kapal merupakan suatu organisasi kecil dan dengan lingkungan yang terbatas, maka keharmonisan anak buah kapal dan semangat kerja yang tinggi memiliki peranan penting dalam meningkatkan kinerja para pelaut di atas kapal.

Awalnya, kepemimpinan dipercaya oleh masyarakat dahulu bahwa kepemimpinan merupakan suatu bapak yang tidak semua orang dapat memiliki bakat kepemimpinan karena kepemimpinan merupakan kemampuan yang dibawa sejak lahir. Sehingga banyak orang yang berpendapat bahwa teori dan ilmu kepemimpinan tidak dibutuhkan.

Kepemimpinan dapat sukses dijalankan tanpa didasari oleh teori, tanpa pelatihan dan pendidikan sebelumnya. Kepemimpinan adalah jenis pemimpin yang tidak ilmiah yang dilakukan berdasarkan bakat menguasai seni memimpin. Dalam perkembangannya, kepemimpinan secara ilmiah bermunculan dan terus berkembang seiring dengan pertumbuhan manajemen ilmiah (scientific managemen), yang dipelopori oleh ilmuwan Frederick W. Taylor abad ke-20 dan perkembangannya memunculkan satu ilmu kepemimpinan yang tidak didasari dari bakat dan pengalaman saja, tetapi mempersiapkan secara berencana dan melatih yang dilakukan dengan perencanaan, percobaan, penelitian, analisis, supervisi dan penggemblengan secara sistematis untuk membagikan sifatsifat pemimpin yang unggul, agar mereka berhasil dalam setiap tugasnya.

Berkembangnya ilmu kepemimpinan, kepemimpinan berdasarkan bakat alam tidak lagi menjadi acuan, namun kepemimpinan melalui pelatihan dan pendidikan menjadi kemampuan untuk memengaruhi menggerakkan suatu karya bersama. Kepemimpinan adalah suatu kekuatan yang menggerakkan perjuangan atau kegiatan yang menuju sukses. Kepemimpinan dapat juga diartikan sebagai proses memengaruhi atau memberi contoh oleh pemimpin kepada pengikutnya dalam upaya mencapai tujuan organisasi.

Kepemimpinan merupakan proses mempengaruhi aktivitas kelompok dalam rangka perumusan dan pencapaian tujuan. Kepemimpinan berasal dari kata pemimpin. Pengertian pemimpin adalah suatu peran atau ketua dalam sistem di suatu organisasi atau kelompok. Sedangkan kepemiminan merupakan kemampuan yang dimiliki seseorang untuk memengaruhi orang-orang untuk bekerja mencapai tujuan dan sasaran.

a. Hal-hal yang menyebabkan Nakhoda memotivasi semangat kerja ABK di atas kapal ialah :

1. Gaya kepemimpinan Nakhoda

Kepemimpinan di atas kapal turut mempengaruhi motivasi kerja kru. Gaya kepemimpinan yang dimaksud adalah cara Nakhoda menjalankan kepemimpinannya sehingga dapat memberi dorongan pada kru untuk 
bekerja secara efektif dan efisien. Dalam penelitian ini kepemimpinan Nakhoda dititikberatkan pada dua hal pokok yaitu gaya kepemimpinan dan kemampuan kepemimpinan untuk mengarahkan dan memberi bimbingan kepada bawahan untuk bekerja dengan baik. Dikatakan bahwa gaya kepemimpinan di atas kapal sangat baik bila Nakhoda bersikap ramah dan memberikan kesempatan kepada kru untuk menyampaikan ide-ide mereka.

Pemimpin itu mempunyai sifat, kebiasaan. Temperamen, watak, dan kepribadian sendiri yang unik dan khas, sehingga tingkah laku dan gayanya sendiri membedakan dirinya dengan orang lain. Gaya atau style hidupnya pasti akan mewarnai perilaku dan tipe kepemimpinannya.

Tipe kepemimpinan Nakhoda pada kapal ini yaitu kepemimpinan suportif di mana Nakhoda bersikap ramah dan menunjukkan perhatian kepada kru atau bawahannya. Gaya kepemimpinan Nakhoda tersebut dapat meningkatkan kerja kru di atas kapal.

\section{Pemberian Motivasi Secara \\ Langsung \\ Motivasi adalah dorongan yang} dimiliki individu yang merangsang untuk melakukan tindakan atau kegiatan dalam mencapai tujuan yang diharapkan pada penelitian ini pemberian motivasi dititikberatkan pada pemberian himbauan agar kru menyelesaikan tugas dan tanggung jawabnya sehingga tidak terjadi penumpukan pekerjaan.

Motivasi yang baik dapat diukur dari tingginya semangat kerja kru dalam melaksanakan tugas pokok tepat waktu sedangka motivasi yang kurang dapat pula dilihat dari rendahnya gairah dan semangat kerja kru dalam melaksanakan tugas pokok sehingga sering terjadi penundaan dalam menyelesaikan pekerjaan.

\section{Kebijaksanaan}

Kebijaksanaan merupakan sifat dan kemampuan untuk menggunakan pengetahuan, pemahaman, pengalaman, akal sehat dan wawasan yang dalam.

Kebijaksanaan adalah akumulasi dari ilmu, pengetahuan, dan pencerahan. Orang yang bijaksana mempunyai kualitas dalam berpengetahuan, serta mempunyai kapasitas untuk menggunakannya. Dia mengetahui masukan yang baik serta dapat mengolahnya menjadi hasil yang baik. Dia mempunyai ketajaman akal, adil, cerdas, dan mahir tentang ilmu pengetahuan tertentu.

Kebijaksanaan merupakan salah satu faktor yang mempengaruhi motivasi kerja kru. Kebijaksanaan yang dimaksud penelitian ini adalah meliputi peraturan-peraturan di atas kapal yang menyangkut tata kerja dan mekanisme kerja kru. Mengenai tata kerja, penelitian yang diadakan memperhatikan bahwa perintah atau instruksi yang dibuat Nakhoda belum tentu memadai.

Dengan adanya perintah dan intruksi yang jelas dapat memudahkan kru dalam bekerja sehingga dapat meningkatkan motivasi kerja mereka, hal ini dapat dilihat dari pendapat kru terhadap pengaruh kebijaksanaan yang dibuat Nakhoda.

\section{Lingkungan Kerja}

Lingkungan kerja dalam suatu perusahaan termasuk salah satu hal yang penting untuk diperhatikan. Meskipun lingkungan kerja tidak melaksanakan proses produksi dalam suatu perusahaan, namun lingkungan kerja mempunyai pengaruh langsung terhadap para karyawan yang melaksanakan proses produksi tersebut. Lingkungan kerja yang memusatkan bagi karyawannya dapat meningkatkan kinerja. Sebaliknya lingkungan kerja yang tidak memadai akan dapat 
Firdaus Sitepu

menurunkan kinerja dan akhirnya menurunkan motivasi kerja karyawan.

$$
\text { Lingkungan kerja juga }
$$

mempengaruhi semangat kerja kru. Lingkungan kerja yang dimaksud adalah keadaan di mana kru dapat bekerja dengan tenang dan nyaman sehingga benar-benar dapat meningkatkan motivasi kerjanya. Penelitian ini dititikberatkan pada bagaimana Nakhoda menciptakan suasana kerja yang nyaman dengan selalu siap memberikan petunjuk dan pengarahan terhadap masalah-masalah yang timbul dalam pelaksanaan tugas dan tanggung jawab kru dalam menyelesaikan pekerjaannya.

Lingkungan kerja yang baik akan berpengaruh positif terhadap motivasi kerja kru dalam menyelesaikan tugas dan tanggung jawabnya, hal ini dapat dilihat dari pendapat kru tentang pengaruh lingkungan kerja terhadap motivasi kerja kru.

b. Nakhoda Mempuyai Wewenang dan Tanggung Jawab Penuh Bagi Keselamatan Kapal, Kru, Muatan dan Penumpang.

Setiap kapal laut dipimpin oleh seorang Nakhoda, di mana seorang Nakhoda bertanggung jawab atas keselamatan. Nakhoda adalah pemimpin kapal, yaitu seorang tenaga kerja yang telah menandatangani perjanjian kerja laut dengan perusahaan pelayaran sebagai Nakhoda ,yang memenuhi syarat dan tercantum dalam sijil anak buah kapal sebagai Nakhoda ditandai dengan mutasi dari perusahaan dan pencantuman namanya dalam surat laut.

Seorang Nakhoda dalam menjalankan tugasnya sehari-hari di atas kapal mempunyai jabatan-jabatan sebagai berikut:
1) Nakhoda sebagai pemimpi kapal Nakhoda merupakan pemimpin tertinggi dalam mengelola, melayarkan dan mengarahkan kapal tersebut. Hal yang lebih penting lagi adalah Nakhoda sebagai pemimpin kapal harus melayarkan kapalnya dari suatu tempat ke tempat lain dengan aman, tepat waktu, praktis dan selamat.

2) Umum

Nakhoda bertugas untuk menertipkan kapal. Anak buah kapal harus patuh kepadanya, dengan konsekuensi sebaliknya setiap perintah Nakhoda yang tidak pantas boleh diadukan kepada pihak yang berwenang oleh anak buah kapal.

3) Nakhoda sebagai jaksa atau abdi hukum

Nakhoda dalam mengatasi atau menanggulangi suatu perkara atau kejahatan diperbolehkan menahan seseorang untuk pengamanan dan pengusutan perkaranya, yang kemudian dituangkan dalam sebuah berita acara untuk kemudian diserahkan kepada kepolisian atau kejaksaan di pelabuhan berikutnya.

4) Nakhoda sebagai pegawai pencatatan sipil

Dalam suatu perjalanan pelayaran dapat saja terjadi hal-hal menyangkut kehidupan manusia, seperti kelahiran, kematian, perkawinan, dan lain-lain. Namun kemungkinan yang benar-benar terjadi hanyalah kelahiran dan kematian maka Nakhoda diberi tugas sebagai pegawai catatan sipil dengan mencatat semua kejadian di dalam buku harian kapal dengan disaksikan oleh dua orang saksi.

5) Nakhoda sebagai notaris

Nakhoda dapat bertindak sebagai notaris dalam pembuatan surat wasiat di atas kapal. 
6) Nakhoda sebagai wakil perusahaan pelayaran

7) Nakhoda sebagai pemilik muatan Dalam kasus-kasus tertentu, Nakhoda juga dapat menjabat sebagai wakil pemilik muatan, baik ia sebagai pengirim atau penerima.

c. Kurangnya Motivasi Kerja Kru Kapal Motivasi adalah dorongan yang dimiliki individu yang merangsang untuk melakukan tindakan atau kegiatan dalam mencapai tujuan yang diharapkan. Apabila kurangnya motivasi kru biasanya ditunjukkan dengan menurunnya aktivitas yang terus menerus yang berdampak pada orientasi tujuan organisasi. Kru yang tidak bermotivasi adalah mereka yang termasuk dalam tiga hal berikut ini:

1) Perilaku kru tidak memperlihatkan goal directed (berorientasikan tujuan);

2) Perilaku kru tidak diarahkan pada tujuan yang bernilai bagi organisasi;

3) Kru tidak komitmen terhadap tujuan dan karenanya mudah terganggu dan menuntut pengawasan yang tinggi.

d. Harus ada komunikasi yang baik antara Nakhoda Dengan ABK

Buruknya kepemimpinan nakhoda dapat mempengaruhi penurunan kinerja anak buah kapal dan terjadinya kesalahpahaman dalam berkomunikasi akibat dari tata cara penyampaian tutur kata yang tidak benar dan kurang tepat sasaran. Menyampaikan suatu panggilan hendaknya sesuai dengan tugas perorangan yang sudah terorganisir di kapal, diantara penyampaian berita atau komunikasi tersebut sebagai seorang nakhoda harus dapat menyampaikan cara berkomunikasi dengan baik, jelas dan dapat dimengerti oleh semua bawahannya. Seorang nakhoda dengan kurang memiliki tata cara maupun teknik-teknik tertentu untuk menciptakan hubungan kerja yang selaras dan baik antara sesama awak kapal, bawahan dan atasan maupun sebaliknya antara atasan dan bawahan, serta kurangnya komunikasi.

Dalam pelaksanaan kerja di atas kapal sehingga timbul berbagai masalah yang diakibatkan tidak terciptanya saling hormat menghormati antara sesama ABK, baik atasan maupun bawahan dengan tetap memegang teguh tanggung jawab wewenang dari masing-masing individu yang bekerja di atas kapal. Sifat-sifat kepemimpinan yang diperlukan (seperti diuraikan dalam Manajemen Kepemimpinan (Karyadi M. : 2008), Kepemimpinan, disusun oleh H. Muhir Subagia, PB PGRI) diantaranya sebagai berikut :

1) Jujur;

2) Berpengalaman;

3) Berani;

4) Mampu mengambil keputusan;

5) Dapat dipercaya;

6) Berinisiatif;

7) Bijaksana;

8) Tegas;

9) Adil;

10) Menjadi tauladan;

11) Tahan uji;

12) Tidak mementingkan diri sendiri;

13) Simpatik;

14) Rendah hati.

Sifat kepemimpinan merupakan kualitas pribadi seseorang yang amat berharga bagi seorang pemimpin dalam menjalankan kepemimpinannya dan merupakan sikap dan tingkah laku yang dapat dilihat dan dicontoh oleh lingkungannya. Oleh karena itu sifatsifat kepemimpinan dapat dipelajari dengan menjalani dan memahami sifatsifat kepemimpinan seseorang. Pemimpin dapat menganalisa dirinya guna kepentingannya. Kemampuan memimpin atau kepemimpinan yang sangat bergantung pada kualitas jiwa 
Firdaus Sitepu

dan sifat seseorang akan berhasil menjalankan kepemimpinannya tergantung kemampuan, usaha dan kegiatan orang itu sendiri dalam mengembangkan serta meningkatkan kualitas pribadinya (self improvement). Kepemimpinan sebagai ilmu di dalam pelaksanaannya harus disesuaikan dengan keadaan dan lingkungan serta anggota bawahan yang dihadapi untuk tipe kepemimpinan di laut yang cocok dipakai/dianut yaitu tipe kepemimpinan otoriter dan demokrasi, maksudnya adalah tipe ini melakukan pimpinan pekerjaan atau kehendak yang diinginkan bersama dengan bawahannya.

\section{KESIMPULAN}

Motivasi dari para kru di atas kapal sangat dipengaruhi oleh peran Nakhoda karena secara umum para kru mempunyai semangat dan tanggung jawab dengan adanya motivasi dan dorongan dari Nakhoda. Dari gaya kepemimpinan hingga kebijakan yang diberikan.

Saran peneliti pada penelitian ini adalah bahwa Nakhoda harus melaksanakan perannannya di atas kapal agar menjadi contoh bagi kru kapal bisa lebih termotivasi dalam bekerja.

\section{DAFTAR PUSTAKA}

Faustino. 2004. Pemimpin dan Kepemimpinan. Jakarta: Ghalia Indonesia

Hasibuan, Melayu. 2003. Organisasi dan Motivasi. Jakarta: Bumi Aksara

Kartono, Kartini. 1985. Pemimpin dan Kepemimpinan. Jakarta: Rajawali Press
Thoha, Miftah. 2005. Perilaku Organisasi. Jakarta: Raja Garfindo Persada

https://www.scribd.com/document/268700 789/009-NAUTIKA 